\title{
DESAIN BAHAN AJAR BERBASIS KEMAMPUAN KONEKSI MATEMATIS SISWA SMP PADA KELAS VII
}

\author{
Dani Syahrul Fajar ${ }^{1)}$, Ika Wahyuni ${ }^{2)}$, Dina Pratiwi Dwi Santi ${ }^{3)}$ \\ ${ }^{122) 3)}$ Program Studi Pendidikan Matematika, FKIP, Universitas Gunung Jati Cirebon, \\ Indonesia \\ danisyahrulf30@gmail.com;ik.math84@gmail.com ; dinapratiwids@fkip- \\ unswagati.ac.id
}

\begin{abstract}
The background of this research is the learning obstacle on the material of the VII grade MTs algebraic operating material. This study aims to describe how the design of didactic teaching materials based on the mathematical connection ability of junior high school students in class VII. Subjects in this study were students of MTs PUI Majalengka, 28 students of class VII A to identify learning obstacles and 10 students of class VII A were used as samples for the implementation of teaching materials. The research carried out was a didactic design research consisting of three stages, namely: (1) didactic situation analysis prior to learning in the form of a Didactic Design Hypothesis including ADP, (2) methadactic analysis, and (3) retrosfective analysis. How to collect data by tests, validation of teaching materials, and student questionnaire responses. The results showed that there were three types of obstacle learning. The validation results obtained can be concluded that teaching materials based on students' mathematical connection abilities can be used in learning algebraic form operations. The implementation of this didactic design is in accordance with predictions so that the design of this teaching material can be used as an alternative design of learning algebraic operations learning.
\end{abstract}

Keywords : Learning Obstacle, Design of teaching materials, Operations of algebraic forms, Mathematical Connection Ability, Jerome S.Brunner Theory

ABSTRAK
Latar belakang dari penelitian ini salah satunya adalah learning obstacle pada materi
operasi bentuk aljabar MTs kelas VII. Penelitian ini bertujuan untuk mendeskripsikan
bagaimana desain bahan ajar didaktis berbasis kemampuan koneksi matematis siswa
SMP pada kelas VII. Subjek dalam penelitian ini adalah siswa MTs PUI Majalengka
yaitu 28 orang siswa kelas VII A untuk identifikasi learning obstacle dan 10 orang
siswa kelas VII A digunakan sebagai sampel untuk implementasi bahan ajar. Penelitian
yang dilakukan merupakan penelitian desain didaktis yang terdiri dari tiga tahap yaitu:
(1) analisis situasi didaktis sebelum pembelajaran yang wujudnya berupa Desain
Didaktis Hipotesis termasuk ADP, (2) analisis metapedadidaktik, dan (3) analisis
retrosfektif. Cara pengambilan data dengan tes, validasi bahan ajar, dan angket respons
siswa. Hasil penelitian menunjukkan bahwa terdapat tiga tipe learning obstacle. Hasil
validasi yang diperoleh dapat disimpulkan bahwa bahan ajar berbasis kemampuan
koneksi matematis siswa dapat digunakan dalam pembelajaran operasi bentuk aljabar.
Implementasi desain didaktis ini sesuai dengan prediksi sehingga desain bahan ajar ini
dapat dijadikan alternatif desain pembelajaran operasi bentuk aljabar.


Kata Kunci : Learning Obstacle, Desain bahan ajar, Operasi bentuk aljabar, Kemampuan Koneksi Matematis, Teori Jerome S.Brunner.

\section{PENDAHULUAN}

Terdapat beberapa faktor yang mempengaruhi tujuan pembelajaran, seperti ketersedian bahan ajar dan tingkat kemampuan koneksi matematis siswa terhadap materi pada bahan ajar. Salah satu materi pada pembelajaran matematika SMP kelas VII semester 1 adalah operasi bentuk aljabar. Ada beberapa kompetensi dasar yang harus dicapai pada materi operasi bentuk aljabar, yaitu: memahami konsep dasar operasi bentuk aljabar, menentukan penyederhanaan bentuk aljabar, danmengubah soal verbal kedalam bentuk model matematika.

Berdasarkan hasil uji coba yang dilakukan di kelas VIIA MTs PUI Majalengka. Siswa mengalami kesulitan terkait dengan menyederhanakan operasi bentuk aljabar dan mengubah soal ke dalam bahasa matematika. Hal ini disebabkan oleh terbatasnya pengetahuan siswa terhadap konten tertentu sehingga tidak dapat mengaitkan antara konsep yang satu dengan yang lainnya. Kesulitan seperti ini dikenal dengan hambatan epistimologis.

Menurut Duroux (Maharani, 2014). hambatan epistimologis merupakan kemampuan pengetahuan seseorang yang hanya terbatas pada konteks tertentu.Jika siswa mengalami hambatan dalam proses pembelajaran maka hambatan tersebut dapat menyebabkan siswa mengalami kegagalan atau setidaknya kurang berhasil dalam mencapai tujuan pembelajaran. Disinilah tugas seorang guru untuk menimalisir hambatan yang dapat muncul dalam proses pembelajaran. Salah satu faktor yang berpengaruh dalam meningkatkan pemahaman konsep siswa adalah kemampuan guru dalam mengembangkan bahan ajar. Menurut Maharani, dkk (2014), aspek materi pendidikan yang disesuaikan dengan prilaku yang dapat digunakan sebelum proses pembelajaran dimulai. Sebaiknya guru mempersiapkan bahan ajar yang akan digunakan serta strategi pencapaiannya sehingga bahan ajar tersebut dapat mudah dipahami dan membantu siswa belajar secara mandiri.

Salah satu bentuk bahan ajar yang dapat digunakan guru dalam proses pembelajaran adalah modul berbasis teori Brunner. Modul berbasis teori Brunner pada penelitian ini memuat unsur-unsur yang dikemukakan oleh (Hamdani, 2012) sebagai berikut. (1) Judul, mata pelajaran, kompetensi inti, kompetensi dasar, indikator; (2) Petunjuk belajar; (3) Kompetensi yang akan dicapai.; (4) Informasi pendukung, informasi ini ditunjukkan agar siswa dapat lebih tertarik atau memperjelas suatu sub bahasan dari bahan ajar tersebut; (5) Latihan-latihan; (6) Petunjuk kerja; (7) Evaluasi.

Bruner (Lindqvist, 2010) mengemukakan interaksi sosial dalam mengubah proses psikologi dengan melalui tiga tahapan yaitu tahapa enaktif dengan menghubungkan dalam kehidupan sehari-hari, tahap ikonik 
dengan memahami objek-objek dunia nyata melalui gambar dari visualisasi, dan tahap simbolik yaitu dengan memiliki ide atau gagasan melalui simbol dapat membantu siswa menuntaskan masalah tertentu melalui perkembangannya dengan bantuan guru, teman atau orang lain yang memilki kemampuan tinggi. Modul ini dibuat sesuai dengan tujuan pembelajaran Brunner untuk mengetahui peningkatan kemampuan koneksi matematis.

Menurut NCTM (Harahap, 2015) koneksi matematika diklasifikasikan menjadi 3 jenis yaitu koneksi antar topik matematika, koneksi dengan disiplin ilmu diluar matematika dan koneksi dengan dunia nyata atau kehidupan sehari-hari. Sedangkan menurut Sumarmo (Harahap, 2015) mengemukakan indikator dari kemampuan koneksi matematis yaitu mencari hubungan berbagai representasi konsep dan prosedur, memahami hubungan di antara topik matematika, menerapkan matematika dalam bidang studi lain atau kehidupan sehari-hari, memahami representasi ekuivalen suatu konsep, mencari hubungan suatu prosedur dengan prosedur lain dalam representasi yang ekuivalen,dan menerapkan hubungan antar topik matematika, dan antar topik matematika dengan topik di luar matematika. Indikator kemampuan koneksi matematis yang akan digunakan dalam penelitian ini adalah mencari hubungan berbagai representasi konsep dan prosedur, memahami hubungan di antara topik matematika dan menerapkan matematika dalam bidang studi lain atau kehidupan sehari-hari.
Bahan ajar ini dirancang untuk mengetahui adanya peningkatan koneksi matematis siswa dengan menggunakan bahan ajar teori Brunner dan model discovery learning dalam proses pembelajaran. Dalam proses pembelajaran guru dan siswa tidak dapat terlepas dari aktivitas yang dilakukan selama proses pembelajaran berlangsung. Dengan demikian aktivitas guru dan siswa akan dinilai oleh observer selama proses pembelajaran. Menurut Dierich (Hamalik, 2010) mengklasifikasikan aktivitas siswa menjadi 8 yaitu: visual, lisan, mendengarkan, mental, menulis, menggambar, metrik dan emosional sedangkan kegiatan guru diantaranya adalah menjelaskan, mengatur jalan kegiatan belajar juga membimbing siswa dalam belajar. Jadi, aktivitas kemampuan koneksi matematis adalah kegiatan yang dilakukan dimana kemampuan dasar yang mengaplikasikan matematika dalam menyelesaikan masalah nyata/kehidupan sehari-hari, kemampuan matematika digunakan dalam menyelesaikan masalah antar topik matematika dan ilmu diluar matematika, kegiatan ini dilakukan oleh siswa dan guru dalam kegiatan belajar mengajar.

Berdasarkan uraian di atas, maka diperlukan penelitian mengenai desain bahan ajar terkait teori Bruner pada kemampuan koneksi matematis siswa SMP khususnya pada materi operasi bentuk aljabar. untuk itulah penulis tertarik melakukan penelitian desain bahan ajar operasi bentuk aljabar berbasis teori kemampuan koneksi 
matematis siswa. Adapun tujuan yang ingin dicapai dalam penelitian ini yaitu: mempunyai tujuan untuk mendeskripsikan bagaimana desain bahan ajar didaktis berbasis kemampuan koneksi matematis siswa SMP pada kelas VII.

\section{LANDASAN/KAJIAN TEORI}

\section{Kemampuan Koneksi Matematis}

Kutz (1991) berpendapat bahwa koneksi matematis berkaitan dengan koneksi internal dan koneksi eksternal. Koneksi internal meliputi koneksi antar topik matematika sedangkan koneksi eksternal meliputi koneksi dengan mata pelajaran lain dan koneksi dengan kehidupan sehari-hari. Sedangkan Sumarmo (1996) membagi koneksi matematika menjadi lima macam, yaitu (1) koneksi antar topik dalam matematika, (2) koneksi antara beberapa macam tipe pengetahuan, (3) koneksi antara beberapa macam representasi, (4) koneksi dari matematika ke daerah kurikulum lain, dan (5) koneksi siswa dengan matematika.

$$
\text { Menurut Kusuma (2008) }
$$

koneksi matematis, sebagai bagian dari kemampuan berfikir matematis tingkat tinggi, dapat diartikan sebagai keterkaitan antara konsep-konsep matematika secara internal yaitu berhubungan dengan matematika itu sendiri ataupun keterkaitan secara eksternal, yaitu matematika dengan bidang lain, baik bidang studi lain maupun dengan kehidupan sehari-hari. Mikovch dan Monroe (1994) mengatakan ada 3 koneksi matematika yaitu: (1) koneksi dalam matematika.
(2) koneksi dengan bidang studi lain

(3) koneksi dengan dunia nyata.

\section{Learning Obstacle}

Brousseau (Suryadi, 2010) mengatakan bahwa terdapat tiga faktor penyebab munculnya hambatan belajar, yaitu hambatan ontogeni, hambatan didaktis, dan hambatan epistemologi. Hambatan ontogeni adalah hambatan yang disebabkan oleh kurangnya kesiapan mental belajar siswa dalam menghadapi proses pembelajaran. Hambatan didaktis yaitu kurangnya kesiapan guru dalam menghadapi proses pembelajaran. Hambatan Epistemologi adalah hambatan yang disebabkan oleh pengetahuan siswa yang memiliki konteks aplikasi yang terbatas. Dengan mengidentifikasi learning obstacles tersebut akan diketahui permasalahan-permasalahan yang terjadi saat pembelajaran matematika khususnya persamaan kuadrat berlangsung, sebagai dasar pengembangan desain didaktis hipotetik.

\section{METODE PENELITIAN}

Jenis Penelitian

Metode penelitian yang digunakan adalah metode kualitatif. Metode kualitatif yaitu metode penelitian yang berlandaskan pada filsafat postpositivisme, digunakan untuk meneliti kondisi objek yang alamiah dimana peneliti adalah sebagai instrumen kunci (Mazgon dan Stefanc, 2012).

\section{Waktu dan Tempat Penelitian}

Penelitian dilakukan pada tanggal Juni 2018 untuk identifikasi learning obstacle dan implementasi Oktober 
2018 di MTs PUI Majalengka tahun ajaran 2018/2019.

\section{Subjek Penelitian}

Subjek untuk mengidentifikasi learning obstacle yaitu siswa kelas VII MTs PUI Majalengka sebanyak 28 siswa dan 10 orang siswa kelas VII A digunakan sebagai sampel untuk implementasi bahan ajar.

\section{Prosedur Penelitian}

Inti dari penelitian ini yaitu menyusun desain didaktis berdasarkan learning obstacle terkait materi operasi bentuk aljabar yang ditemukan sehinga meminimalkan learning obstacle pada materi tersebut. Menurut Kusnadi, dkk. (2016) analisis disain didaktis pada dasarnya terdiri atas tiga tahap yaitu (1) analisis situasi didaktis sebelum pembelajaran yang wujudnya berupa disain didaktis hipotesis termasuk ADP (Antisispasi Didaktis dan Pedagogis); (2) analisis metapedadidaktik; dan (3) analisis retrosfektif yakni analisis yang mengaitkan hasil analisis situasi didaktis hipotesis dengan hasil analisis metapedadidaktis

\section{Instrumen Penelitian}

Instrumen yang digunakan dalam penelitian ini adalah tes kemampuan koneski materi operasi aljabar untuk mengetahui learning obstacle, angket respons siswa dan validasi bahan ajar dilakukan untuk mengetahui kelayakan bahan ajar yang akan digunakan dalam implementasi.

\section{Teknik Pengumpulan Data}

Teknik pengumpulan data dalam penelitian ini adalah tes, angket dan validasi bahan ajar. Tes dilakukan untuk mengetahui learning obstacle, angket dilakukan untuk mengetahui respons siswa dan validasi bahan ajar dilakukan untuk mengetahui kelayakan bahan ajar yang akan digunakan dalam implementasi. Sedangkan analisis data dilakukan dengan terlebih dahulu mengumpulkan seluruh data yang diperoleh untuk selanjutnya dilakukan penyelesaian dan pengelompokan data yang ada kemudian melakukan interpretasi secara naratif.

\section{Teknik Analisis Data}

Disain didaktis pada dasarnya terdiri atas tiga tahap yaitu: (1) analisis situasi didaktis sebelum pembelajaran yang wujudnya berupa disain didaktis hipotesis termasuk ADP (Antisispasi Didaktis dan Pedagogis), (2) analisis metapedadidaktik, dan (3) analisis retrosfektif yakni analisis yang mengaitkan hasil analisis situasi didaktis hipotesis dengan hasil analisis metapedadidaktis.

Tahap I: Analisis situasi didaktis sebelum pembelajaran

1. Menentukan materi matematika yang akan dijadikan bahan penelitian.

2. Membuat soal uji coba bentuk aljabar terkait indikator kemampuan koneksi matematis.

3. Melakukan uji instrumen learning obstacle dari soal yang telah diuji 
cobakan untuk mengidentifikasi learning obstacle.

4. Mengembangkan instrumen learning obstacle dengan menyusun indikator kemampuan mengerjakan soal pada tiap nomornya, dan membuat/memilih soal-soal yang variatif serta dapat memunculkan kesulitan siswa mengenai konsep bentuk aljabar.

5. Mengelompokkan jenis kesulitan siswa sesuai dengan indikator kemampuan.

6. Membuat lintasan belajar untuk mempelajari materi bentuk aljabar.

7. Mengembangkan desain didaktis berdasarkan learning obstacle yang muncul dan menyesuaikan dengan teori belajar Brunner.

8. Membuat pediksi respons siswa terhadap desain didaktis yang akan diimplementasikan dan mempersiapkan antisipasi didaktisnya.

9. Melakukan validasi ahli agar modul valid.

10. Menganalisis hasil validasi pada setiap validator untuk mengetahui kelayakan bahan ajar yang dibuat.

Tahap II: Analisis metapedadidaktik

1. Melakukan implementasi desain didaktis yang telah dibuat.

2. Menganalisis hasil implementasi desain didaktis berbagai respons siswa saat implementasi desain didaktis

Tahap III: Analisis retrosfektif

1. Mengaitkan antara prediksi awal yang telah dibuat sebelum implementasi dengan respons siswa saat implementasi berlangsung sebagai rujukan untuk revisi desain didaktis.

2. Mengukur peningkatan desain didaktis dengan melakukan pengujian instrumen learning obstacle kepada siswa yang telah menerima pembelajaran menggunakan desain didaktis kemudian menganalisis hasil pengujian instrumen learning obstacle tersebut untuk melihat apakah kesulitan siswa yang telah teridentifikasi sebelumnya masih muncul atau tidak.

\section{HASIL DAN PEMBAHASSAN}

\section{Learning obstacle terkait rumus yang disesuaikan dengan soal}

Learning obstacle terkait rumus yang disesuaikan dengan soal terdapat pada soal nomor 1, 3 dan 7. Kesulitan siswa dalam mengerjakan soal-soal tersebut disebabkan kurangnya kemampuan mencari hubungan berbagai representasi dan menentukan rumus sesuai dengan konsep operasi bentuk aljabar. Hal ini terjadi karena konsep operasi bentuk aljabar yang dipelajari oleh siswa bersumber dari yang guru sampaikan bukan dari siswa yang mengalami hambatan epistimologis, jika dihadapkan dengan konteks berbeda maka pengetahuan yang dimiliki menjadi tidak bisa digunakan atau siswa mengalami kesulitan untuk mengungkapkannya (Tamba, 2014).

Alternatif yang dirancang untuk menyelesaikan permasalahan pada tipe 
ini yaitu siswa diingatkan kembali mengenai konsep operasi bentuk aljabar, dan siswa diberikan penjelasan mengenai pemfaktoran suatu bilangan. Menurut Bruner (Suprijono, 2011) seperangkat dari pemahaman bahwa proses belajar adalah adanya pengaruh kebudayaan terhadap tingkah laku individu, maka perkembangan kognitif individu terjadi melalui tiga tahap yang ditentukan oleh caranya melihat lingkungan. Tahap itu meliputi enaktif (enactive), ikonik (iconic) dan simbolik (symbolic).

\section{Learning obstacle terkait membuat} model matematika pada materi operasi bentuk aljabar

Learning obcatacle terkait membuat model matematika dari bentuk verbal yang diketahui daerah penyelesaiannya dan bentuk verbal terdapat pada soal nomor 4, 5 dan 6 . Kesulitan siswa dalam mengerjakan soal tersebut disebabkan karena siswa tidak dapat mengubah soal bentuk verbal menjadi model matematika.

Kekeliruan siswa dalam membuat model matematika merupakan suatu hambatan dalam proses pembelajaran sehingga hambatan itu dapat menyebabkan siswa mengalami kegagalan atau setidaknya kurang berhasil dalam mencapai tujuan belajar (Kusnadi, 2016). Melihat permasalahan yang ada Utami diperlukan bahan ajar yang lebih lengkap dan mampu memfasilitasi siswa untuk belajar mandiri dan memudahkan siswa dalam menemukan konsep dasar matematika dengan benar.
Alternatif yang dapat digunakan untuk mengatasi hambatan belajar tipe ini yaitu dengan memberikan contoh yang disesuaikan dengan soal bentuk verbal yang akan diubah ke dalam model matematika. Selain itu, alternatif lain yang dapat digunakan yaitu dengan membuat tabel pemisalahan pada setiap variabel dengan demikian siswa secara tidak langsung melakukan tahapan ikonik. Menurut Bruner (Suprijono, 2011) Tahap ikonik (iconic), yaitu individu memahami objek-objek dunianya melalui gambar dari visualisasi verbal. Memahami dunia sekitarnya dengan bentuk perumpamaan dan perbandingan. Kemudian, siswa diberikan stimulus mengenai konsep operasi bentuk aljabar pada bentuk verbal.

\section{Learning obstacle terkait penyederhanaan operasi bentuk aljabar}

Learning obstacle terkait penyederhanaan operasi bentuk aljabar pada soal nomor 2 dan 8 . Soal nomor 2 , menyajikan soal penyederhanaan operasi bentuk aljabar. Hal ini disebabkan oleh kemampuan siswa hanya sebatas memindahkan bukan memfaktorkan soal yang disajikan kemudian menyederhanakannya. Siswa tidak menekankan untuk giat berlatih mengerjakan soal yang lebih rumit misalnya dengan mengganti angkaangka yang telah disajikan dengan huruf sebagai cara untuk membangun pemahaman siswa dalam konsep operasi bentuk aljabar untuk menyederhanakan suatu bilangan. 
Berdasarkan permasalahan di atas alternatif yang dapat digunakan untuk mengatasi hambatan belajar dalam tipe ini yaitu dengan membimbing siswa menemukan masalah yang dikatahui dan ditanyakan. Menurut Brousseau (Tamba, 2014) learning obstacle yang terjadi adalah learning obstacle tipe Epistimological, bagian terpenting dalam pembalajaran adalah epistimologis karena dalam bagianbagian ini diajarkan konsep-konsep yang penting yang menjadi dasar pembelajaran. Salah satunya ialah dengan merancang situasi belajar yang mampu menekankan siswa mampu memahami konsep penyederhanaan bentuk aljabar. Misalkan, siswa diminta untuk menentukan penyederhanaan bentuk aljabar dari $\frac{9 x^{4} y^{2}}{3 x^{2} y}$.

a. Mendesain bahan ajar berbasis kemampuan koneksi matematis siswa pada materi operasi bentuk aljabar

Tabel 1. Hasil Validasi Bahan Ajar dari setiap Kelompok Indikator

\begin{tabular}{llcc} 
No & \multicolumn{1}{c}{ Kelompok Indikator } & $\begin{array}{c}\text { Hasil } \\
\text { Validasi }\end{array}$ & Interpretasi \\
\hline 1 & Relevansi & $91,67 \%$ & Sangat Valid \\
\hline 2 & Keakuratan & $94,43 \%$ & Sangat Valid \\
\hline 3 & Kelengkapan Sajian & $100,00 \%$ & Sangat Valid \\
\hline 4 & Sistematika sajian & $83,33 \%$ & Sangat Valid \\
\hline 5 & $\begin{array}{l}\text { Kesesuaian sajian dengan tuntutan } \\
\text { pembelajaran yang terpusat pada siswa }\end{array}$ & $83,35 \%$ & Sangat Valid \\
\hline 6 & $\begin{array}{l}\text { Kesesuain bahasa dengan kaidah Bahasa } \\
\text { Indonesia yang Baik dan Benar }\end{array}$ & $91,65 \%$ & Sangat Valid \\
\hline 7 & Teori Belajar Brunner & $91,67 \%$ & Sangat Valid \\
\hline 8 & Aktivitas Koneksi Matematika & $75,00 \%$ & Cukup Valid \\
\hline 9 & Aktivitasdiscovery learning & $100,00 \%$ & Sangat Valid \\
\hline
\end{tabular}

Berdasarkan Tabel $\quad 1$ menunjukkan 1 indikator cukup valid
Desain bahan ajar berbasis kemampuan koneksi matematis siswa selesai dibuat, penulis melakukan validasi kepada para ahli dengan lembar validasi yang telah dibuat sebelumnya untuk mengetahui kevalidan bahan ajar modul tersebut. Modul matematika ini diharapkan dapat mengatasi learning obstacle yang telah teridentifikasi. Modul yang dibuat sesuai dengan tujuan pembelajaran, teori Brunner (Suprijono, 2011) yang melalui tiga tahap yaitu tahap enaktif, ikonik dan simbolik pada kemampuan koneksi matematis siswa, dan situasi didaktis yang bertujuan dapat mengatasi learning obstacle. Hasil perhitunga perindikator pada 24 indikator yang dikelompokkan menjadi 9 aspek penilaian yaitu menunjukkan bahwa 23 indikator sangat valid dan 1 indikator cukup valid, berikut disajikan hasil validasi bahan ajar berdasarkan kelompok indikator. 
kriteria penilaian tersebut. Jadi jika dilihat dari semua perhitungan maka bahan ajar untuk siswa ini sangat valid dan layak digunakan dalam implementasi.

4. Praktikalitas bahan ajar berbasis kemampuan koneksi matematis siswa pada materi operasi bentuk aljabar

Praktikalitas bahan ajar diukur menggunakan angket praktikalitas siswa. Dalam pembuatan angket praktikalitas siswa, menurut Hamdunah (2015) ada tiga aspek yang perlu diperhatikan, yakni aspek kemudahan penggunaan, aspek efisiensi waktu, dan aspek manfaat. Berdasarkan penjelasan angket tersebut angket praktikalitas disusun menggunakan tiga aspek tersebut. Masing-masing indikator memeliki beberapa aspek sehingga dalam angket praktikalitas memiliki 14 aspek yang dinilai oleh siswa. Skala yang digunakan dalam penilaian angket adalah skala likert dengan kriteria SS (sangat setuju), S (setuju), R (ragu), TS (tidak setuju), STS (sangat tidak setuju). Berdasarkan hasil perhitungan angket praktikalitas siswa diperoleh persentase sebesar $87,1 \%$ dengan interpretasi praktis. Berdasarkan perhitungan tersebut maka dapat disimpulkan bahwa bahan ajar operasi bentuk aljabar kemampuan koneksi matematis praktis digunakan oleh siswa dalam pembelajaran matematika.

\section{SIMPULAN DAN SARAN}

\section{Simpulan}

Berdasarkan analisis dari hasil penelitian dan pembahasan, dapat ditarik kesimpulan sebagai berikut.
Tahapan mendesain bahan ajar berbasis kemampuan koneksi matematis siswa pada materi bentuk aljabar yaitu dengan membuat soal berbasis kemampuan koneksi yang di uji cobakan kepada siswa, agar dapat mengetahui kesulitan yang dialami oeh siswa untuk dijadikan antisipasi didaktis dalam membuat desain bahan ajar. Setelah itu, dibuat desain bahan ajar yang kemudian akan divalidasi oleh validasi ahli, validasi pengguna dan validasi audience.

Desain bahan ajar modul siswa dibuat berdasarkan learning obstacle, yang disusun secara sistematis yang mencangkup cover, kompetensi inti, kompetensi dasar, indikator kemampuan, tujuan pembelajaran, kompetensi yang akan dicapai, petunjuk penggunaan bahan ajar, informasi pendukung, materi, contoh soal, latihan, rangkuman, glosarium dan daftar pustaka.

Desain bahan ajar yang diimplementasikan kepada siswa kelas VII A MTs PUI Majalengka diperoleh presentasi keseluruhan dari respons siswa yang diambil dengan menggunakan sampel sebanyak 10 orang.

\section{Saran}

Berdasarkan simpulan dari hasil penelitian dan pembahasan yang telah dilakukan, maka saran yang dapat diberikan adalah sebagai berikut.

Guru sebaiknya mampu memperkirakan hambatan belajar/ learning obstacles yang mungkin muncul di kelas ketika mempersiapkan pembelajaran. Sehingga hambatan belajar tersebut dapat diatasi dan tidak akan terulang lagi di kelas berikutnya. 
Dalam mengimplementasikan bahan ajar sebaiknya disertai dengan adanya arahan dari guru, arahan yang diberikan dapat berupa antisipasi guru dalam mengatasi kekeliruan siswa sehingga siswa tidak keliru dalam menerapkan konsep matematika. Guru diharapkan dapat mengaktifkan siswa dalam proses pembelajaran matematika dan dapat menggunakan berbagai cara dalam meningkatkan kemampuan koneksi matematis siswa, agar siswa mampu memahami dan membangun serta dapat mengembangkan konsep matematika.

Bagi peneliti, hasil penelitian ini dapat dikembangkan kembali dengan melakukan perbaikan instrumen penelitian dan bahan ajar sehingga hasil penelitian yang akan diperoleh menjadi lebih baik dari penelitian sebelum.

\section{DAFTAR PUSTAKA}

Hamdani. (2012). Strategi Belajar Mengajar. Bandung. CV Pustaka Setia.

Hamalik. (2010). Kurikulum dan Pembelajaran. Jakarta : PT.Bumi Aksara.

Harahap, T.H. (2015). Penerapan contextuzl Teaching Learning untuk Meningkatkan Kemampuan Koneksi dan Representasi matematika Siswa kelas VII-2 SMP Nurhasanah Medan Tahun Pelajaran 2012/2013. Jurnal Edu Tech Vol.1 No 1.

Kusnadi, dkk. (2016). Desain Didaktis Konsep Luas Permukaan dan Volume Prisma Dalam Pembelajaran Matematika SMP. Mathaline Jurnal Matematika dan
Pendidikan Matematika. Vol 1. No. 1.

Kurz, R.E.(1991). Annotated Instructor's Edition, Teaching Elementary Mathematics. Baston : Allyn and Bacon

Kusuma, Y.S. (2008). Konsep, Pengembangan dan Implementasi Computer-Based Learning dalam Peningkatan Kemampuan HighOrder Mathematics Thingking. Pidato Pengukuhan Jabatan Guru Besar Pendidikan Matematika Universitas Pendidikan Indonesia, 23 Oktober 2008 di Bandung.

Lestari, K.E. dan Yudhanegara, M.R. (2015). Penelitian Pendidikan Matematika. Bandung: PT Refika Aditama.

Lindqvist, G. (2010). "Vygotsky's Theory of Creativity". Creativity Research Journal, Vol. 8 Juni.

Maharani, dkk (2014). Meningkatkan Kemampuan Pemahaman Matematis Siswa Melalui Problem Posing. Jurnal Euclid, Vol.1, No.1.1(1), 47-54.

Mazgon dan Stefanc. (2012). Importance Of The Various Characteristics of Educational Materials Different Opinions, Diferent Perspectives. The Turkish Online Journal of Educational Technology, volume 11 Issue 3.

Mikovch, A.K and Monroe, E.E (1994). Making Mathematical Connection Across The Curriculum : Activities to Help Teachers Begin. School Science and Mathematics. 94(7) 
Sugiyono. (2015). Metode Penelitian Pendidikan (Pendekatan Kuantitatif, Kualitatif, dan $R \& D)$. Bandung: CV Alfabeta.

Suprijono, A. (2011). Cooperative Learning Teori dan Aplikasi PAIKEM. Yogyakarta : PUSTAKA PELAJAR.

Suryadi, D. (2010). Metapedadidaktik dan Didactical Design Research
(DDR) : Sintesis Hasil Pemikiran Berdasarkan Lesson Study. Bandung : FPMIPA UPI.

Tamba, P.K. (2014). Desain Didaktis Bahan Ajar Pertidaksamaan. Seminar Nasional Pendidikan Matematika Ahmad Dahlan, Desember 2014 p-ISSN : 9 772407-74900. 
